JAMP: Jurnal Adminitrasi dan Manajemen Pendidikan

Volume 3 Nomor 2 Juni 2020, Hal : 131-140

Tersedia Online di http:/journal2.um.ac.id/index.php/jamp/

ISSN 2615-8574 (online)

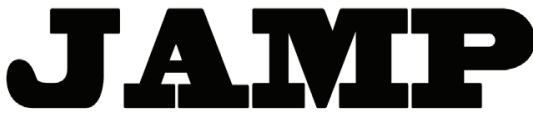

JURNAL ADMINISTRASI DAN MANAJEMEN PENDIDIKAN

\title{
STRATEGI KEPALA SEKOLAH DALAM MENCIPTAKAN BUDAYA RELIGIUS DI SEKOLAH
}

\author{
Asnawi \\ Bambang Budi Wiyono \\ Asep Sunandar \\ E-mail:asnahawk@gmail.com \\ Universitas Negeri Malang, Jalan Semarang No.5 Malang
}

\begin{abstract}
This study aims to find out, (1) steps the school principal creates religious culture, (2) forms of religious culture in schools, (3) ways of socializing and implementing religious culture, (4) support of teachers and school members in creating religious culture, (5) how to overcome the problem of creating a religious culture. This research uses a qualitative approach design, with a case study research design. The location of this research is at Public SHS 9 Malang. Data collection techniques through interviews, observation, and documentation. The analysis technique used is reduction, data display, and data verification. The results of this study (1) the step of the school principal creating a religious culture begins with a meeting consisting of a core team to design an outline of the relevant activities then in consultation with the teachers, (2) the forms of religious culture in the school are Dhuha pray, DhuhurPray and AsrPray in congregation, study of the yellow book, Friday prayers in congregation and princess activities, non-Muslim students religious guidance, training to become qotib, istighosah, ramadhanpondok activities, Commemoration of Islamic Holidays, (3) socialization and implementation of Religious culture through social media, print, electronics, school websites, and verbally. While the implementation is a strategy that has been designed from the stages of planning, implementing, and habituating in daily life in the school environment, (4) teacher and school community support in creating a religious culture including, the teacher goes to the mosque when he hears the call to prayer, starts the lesson by praying, and encourage students to pray Dhuha before the lesson begins, students lead literacy, students become qotib, educational staff every Friday-morning at the morning apple to deliver information on activities carried out on that day. Parental support is parents doing zakat fitrah and zakat mal at school, the establishment of a school mosque is an idea and contribution from parents of students; (5) The way to overcome problems in creating a religious culture is by evaluating systematically and carried out by related parties.
\end{abstract}

Keywords: Strategy, Headmaster, Religious Culture

Abstrak : Penelitian ini bertujuanmengetahui, (1)langkah-langkah kepala sekolah menciptakan budaya religius, (2) bentuk budaya religius di sekolah, (3) cara sosialisasi dan implementasi budaya religius, (4) dukungan guru dan warga sekolah dalam menciptakan budaya religius, (5) cara mengatasi masalah menciptakan budaya religius. Penelitian ini menggunakan rancangan pendekatan kualitatif, dengan rancangan penelitian studi kasus. Lokasi penelitian ini di SMA Negeri 9 Malang. Teknik pengumpulan data melalui wawancara, observasi, dandokumentasi. Teknik analisis yang digunakan yaitu reduksi, display data, dan verifikasi data. Hasil dari penelitian ini (1) langkah kepala sekolah menciptakan budaya religius diawali rapat yang beranggotakan tim inti untuk merancang segara garis besar terkait kegiatan barulah di musyawarahkan dengan para guru, (2) bentuk-bentuk budaya religius yang ada di sekolah adalah Salat Dhuha, Salat Dhuhur dan Ashar berjamaah, kajian kitab kuning, Salat jumat berjamaah dan kegiatan keputrian, siswa non muslim pembinaan keagamaan, pelatihan menjadi qotib, istighosah, kegiatan pondok ramadhan, Peringatan Hari Besar Islam, (3) sosialisasi dan implementasi budaya Religius melalui media sosial, cetak, elektronik, website sekolah, dan secara lisan. Sedangkan implementasinya adalah strategi yang sudah dirancang dari tahap pereencanaan, pelaksanakan, dan pembiasaan 


\begin{abstract}
di keseharian di lingkungan sekolah, (4) dukungan guru dan warga sekolah dalam menciptakan budaya Religius meliputi, guru menuju masjid saat mendengar adzan untuk menunaikan Salat,mengawali pelajaran dengan berdoa, dan menganjurkan siswa untuk Salat Dhuha sebelum pelajaran dimulai, siswa memimpin literasi, siswa menjadi qotib, tenaga kependidikan setiap hari selasa-jumat dilakukan apel pagi untuk penyampaian informasi kegiatan yang dilakukan pada hari itu. Dukungan orangtua adalah orangtua melakukan zakat fitrah dan zakat mal disekolah, berdirinya masjid sekolah merupakan gagasan dan sumbangan dari orangtua siswa; (5) Cara mengatasi masalah dalam menciptakan budaya Religius adalah dengan evaluasi yang dilakukan secara sistematis dan dilaksanakan oleh pihak-pihak terkait.
\end{abstract}

Kata kunci: Strategi, Kepala Sekolah, Budaya Religius

Pendidikan merupakan komponen penting dalam kehidupan manusia. Tanpa adanya pendidikan, kehidupan manusia tidak bisa berkembang secara wajar. Pentingnya sebuah pendidikan maka pendidikan menjadi tolak ukur dalam kredibilitas manusia dan peradabannya. Semakin tinggi pendidikan manusia maka semakin tinggi pula tingkat kredibilitasnya, begitu juga sebaliknya. Pendidikan hendaknya berorientasi pada proses penyiapan peserta didik agar memahami konsep-konsep dalam berperilaku, berfikir secara komprehensif sebagai pijakan dalam menyikapi berbagai problem yang dihadapi (Adha, Supriyanto, \& Timan: 2019). Tujuan Pendidikan menurut As'aril (2011:56) yaitu agar peserta didik mempunyai kompetensi-kompetensi menyangkut ilmu pengetahuan, keterampilan motorik, dan nilainilai moral yang luhur. Pendidikan merupakan bagian yang tidak dapat dipisahkan dari hidup dan kehidupan manusia. Terutama pendidikan agama yang merupakan suatu kebutuhan, fungsi sosial, bimbingan, sarana pertumbuhan yang mempersiapkan dan membentuk disiplin hidup.

Dalam kehidupan ditengah-tengah masyarakat krisis moral yang melanda bangsa ini nampaknya menjadi sebuah kegelisahan bagi semua kalangan. Mulai dari maraknya kasus korupsi yang tidak pernah surut bahkan mengalami peningkatan dari waktu ke waktu. Di sisi lain krisis ini menjadi komplek dengan berbagai peristiwa yang cukup memilukan seperti tawuran pelajar, penyalahgunaan obat terlarang, pergaulan bebas, aborsi, penganiayaan yang disertai pembunuhan. Seperti yang disampaikan Qanita (2016) "Mereka melakukan hal-hal yang dianggap sebagai gaya hidup modern atau gaya hidup budaya luar, misalnya penyalahgunaan narkoba, mengkonsumsi minum-minuman beralkohol atau minuman oplosan (keras) yang dapat menyebabkan kematian, melakukan seks bebas, sehingga hamil di luar nikah yang berpotensi melakukan pernikahan dini ataupun melakukan aborsi, perilaku Lesbian, Gay, Biseks dan Transgender (LGBT) sampai kepada kekerasan seksual yang disertai dengan pembunuhan". Fenomena ini sesungguhnya sangat berseberangan dengan suasana keagamaan dan kepribadian bangsa Indonesia. Jika krisis ini dibiarkan begitu saja dan berlarut-larut apalagi dianggap sesuatu yang biasa maka segala kerusakan moralitas akan menjadi budaya. Sekecil apapun krisis moralitas secara tidak langung akan dapat melemahkan nilai-nilai kehidupan berbangsa dan bernegara, oleh karenanya penting bagi lembaga pendidikan dalam hal ini sekolah untuk meningkatkan moral peserta didik.

Menurut Muhaimin, Sutiah, dan Prabowo (2010:54) nilai-nilai yang menjadi budaya sekolah dapat diprioritaskan meliputi inovatif, adaptif, bekerja keras, peduli, disiplin, jujur, tanggung jawab, rasa memiliki, komitmen terhadap lembaga, dan saling pengertian. Nilai-nilai tersebut dapat diterapkan melalui pola pikir, sikap dan perilaku sehari-hari peserta didik baik melalui pembelajaram, pembiasaan, serta kegiatan-kegiatan keagamaan. Sehingga diharapkan dapat membentuk pola pikir serta tindakan dan karakter peserta didik melalui budaya religius. Budaya religius dalam dunia pendidikan dapat berarti sebagai terwujudnya nilai-nilai perilaku dan cara berpikir yang diajarkan oleh agama dan telah dilakukan oleh seluruh warga sekolah di lembaga pendidikan.

Peneliti memilih SMA Negeri 9 Malang karena sekolah tersebut merupakan sekolah umum negeri yang berada di Kota Malang yang menerapkan budaya Religius pada lingkungan sekolahnya. Sekolah ini memiliki ciri khas, yaitu memadukan pendidikan formal dipadukan nilai-nilai agama secara terpadu dalam pembelajaran maupun dalam pengelolaan sekolah 


\section{METODE}

Penelitian ini menggunakan pendekatan kualitatif, dengan jenis penelitian studi kasus. Teknik pengumpulan data yang digunakan adalah wawacara secara mendalam, observasi lapangan, study dokumentasi. Analisis yang dilakukan dalam penelitian ini dilakukan pada saat pengumpulan data di lapangan. Pada analisis data, peneliti mereduksi data yang telah diperoleh di lapangan, kemudian memilih data sesuai dengan fokus penelitian, selanjutnya membuat kesimpulan pada masing-masing fokus. Pengecekan keabsahan data pada penelitian ini menggunakan teknik triangulasi, ketekunan pengamatan, serta pengecekan anggota.

\section{HASIL}

\section{Langkah-Langkah Kepala Sekolah dalam Menciptakan Budaya Religius}

Langkah-langkah Kepala Sekolah dalam menciptakan budaya religius diawali dengan rapat yang beranggotakan Kepala Sekolah, Unit Penjamin Mutu, Wakil Kepala Sekolah, Bendahara, dan Komite Sekolah. Dalam rapat tersebut dilakukan perencanaan kegiatan apa saja yang akan dilakukan selama setahun kedepan, kemudian menentukan besaran biaya yang akan dikeluarkan dalam kegiatan tersebut, serta juga menentukan siapa saja guru yang terlibat dalam kegiatan tersebut dan membuat susunan panitianya. Hasil dari rapat kecil tersebut kemudian di sampaikan ke forum rapat semua guru untuk menindaklanjuti hasil dari rapat kecil yang sudah dilaksanakan. Dalam rapat bersama guru masih ada kemungkinan perubahan dari rencana kegiatan karena adanya masukan-masukan dari guru.

\section{Bentuk Budaya Religius}

Bentuk-bentuk budaya religius yang ada di SMAN 9 Malang berdasarkan kegiatan yang dilakukan sehari-hari adalah siswa didengarkan lantunan Asmaul Husna ketika siswa tiba disekolah melalui pengeras suara sekolah. Literasi, dilakukan 15menit sebelum pelajaran dimulai, siswa muslim melakukan literasi di kelas masing-masing yang dipandu oleh salah satu siswa membaca ayat Al-Qur'an melalui pengeras suara sekolah. Sedangkan non muslim melaksanakan literasi di aula sekolah berkelompok berdasarkan agama. Berdoa sebelum pelajaran dimulai, dilakukan pada saat sebelum pelajaran dimulai yang dipimpin oleh guru mata pelajaran. Salat Dhuha, saat pelajaran agama diberikan waktu sekitar 10 menit untuk melaksanakan Salat Dhuha, dan pada hari sabtu setelah kegiatan pramuka. Salat Dhuhur dan Ashar berjamaah, Salat Dhuhur dilaksanakan pada istirahat kedua, Salat Ashar dilaksanakan saat setelah bel pulang sekolah. Kultum, setelah adzan Salat Dhuhur siswa siswa diberikan kajian kitab kuning tentang ta'lim muta'alim baru kemudian dilaksanakan Salat Dhuhur berjamaah. Doa sebelum pulang sekolah, salah satu siswa memimpin doa melalui pengeras suara sekolah sebelum pulang ke rumah masing-masing.

Bentuk budaya religius yang dilakukan setiap minggu adalah siswa dilatih untuk bershodaqoh setiap hari jumat ada kotak amal keliling per kelas dan pada saat Salat jum'at. Dilaksanakan Salat jumat berjamaah untuk siswa putra dan kegiatan keputrian untuk siswi putri, sedangkan siswa non muslim ada pembinaan keagamaan. Siswa juga dilatih untuk menjadi qotib Salat jum'at yang dilakukan bergantian dengan guru setiap minggu. Pada hari sabtu setelah siswa melaksanakan kegiatan pramuka dan mendpat materi PPK selanjutnya siswa diarahkan ke masjid untuk Salat Dhuha dan mendpat materi keagamaan tentang tajwid dan tahsin, sedangkan yang non muslim diarahkan ke aula untuk mendapat materi keagamaan sesuai agama masing-masing.

Bentuk budaya religius yang dilakukan setiap bulan adalah kunjungan ke rumah siswa bersama dengan bapak ibu guru, kemudian 2 bulan menjelang ujian nasional siswa kelas 12 melaksanakan istighosah kubro dan diakhir melakukan istighosah bersama dengan orangtua yang dilanjutkan dengan parenting. Bentuk budaya religius yang dilakukan setiap tahun adalah kegiatan pondok ramdhan, peringatan maulid Nabi Muhammad, peringatan hari raya idul adha, peringatan keagamaan untuk non muslim, serta Islamic Competition. 


\section{Sosialisasi dan Implementasi Budaya Religius}

Pihak sekolah dalam mensosialisasikan setiap kegiatan yang dilakukan sekolah adalah dengan melalui media sosial yaitu penyampaian informasi di akun facebook, instagram, serta group whatsapp ketua kelas dan orangtua. Selain menggunakan media sosial pihak sekolah juga menyampaikan informasi kegiatan sekolah melalui media cetak dan elektronik yang mempunyai rekanan di koran Jawa Pos dan Arema Tv, Media online juga digunakan pihak sekolah dalam menyapaikan setiap kegiatan dan pusat informasi sekolah yang ada di website sekolah. Pihak sekolah juga menyampaikan kegiatan-kegiatan dan informasi secara langsung melalui pertemuan wali murid, parenting, dan pada saat pembagian raport.

Sekolah sudah mengimplementasikan strategi yang sudah dirancang dari tahap pereencanaan, pelaksanakan, dan pembiasaan di keseharian di lingkungan sekolah. Seperti siswa menjadi lebih sopan dan santun kepada guru maupun tenaga kependidikan dengan budaya 5S (senyum, sapa, salam, sopan, santun). Siswa juga menjadi disiplin dengan dibiasakannya Salat Dhuhur dan Salat Ashar berjamaah ditunjukan dengan siswa lebih sedikit yang datang terlambat ke sekolah. Siswa juga menjadi lebih dermawan dengan pembiasaan kotak amal keliling setiap hari jumat dan iuran untuk membeli hewan qurban dibuktikan dengan terbangunnya masjid SMAN 9 Malang dan setiap Peringatan Idul Adha sekolah selalu menyembelih hewan qurban.

\section{Dukungan Guru dan Warga Sekolah dalam Menciptakan Budaya Religius}

Dukungan guru terhadap terlaksananya penciptaan budaya religius adalah sebagai berikut guru memberikan contoh yang baik untuk siswanya melalui baris di pagi hari di halaman sekolah untuk menyambut siswa, ke masjid saat bel istirahat berbunyi untuk menjalankan Salat Dhuhur berjmaah, setiap sebelum kegiatan belajar mengajar dimulai diawali dengan berdoa terlebih dahulu, beberapa guru menganjurkan untuk melaksanakan Salat Dhuha terlebih dahulu sebelum pelajaran dimulai, dan selalu mendukung setiap kegiatan budaya religius yang ada disekolah.

Dukungan siswa terhadap terlaksananya penciptaan budaya religius di sekolah adalah sebagai berikut dipilihnya salah satu siswa yang memimpin literasi dan bergantian setiap hari, siswa yang ikut BDI maupun Remas membantu kegiatan religius yang ada di sekolah, misalnya saat penyembelihan hewan qurban siswa ikut membantu memotong dan membagikan hewan qurban, siswa membersihkan dan mempersiapkan masjid yang akan digunakan untuk Salat berjamaah mauapun Salat jum'at, siswa yang diberi tugas untuk menjadi qotib pada saat Salat jum'at, membaca Al-Qur'an di masjid sekolah pada saat bulan Ramadhan.

Dukungan tenaga pendidik terhadap penciptaan budaya religius di sekolah adalah sebagai berikut setiap hari selasa-jumat dilakukan apel pagi untuk tenaga pendidik untuk memberikan informasi terkait kegiatan yang akan dilakukan pada hari itu, sehingga tenaga pendidik bisa mendukung kelancaran kegiatan tersebut dan ikut serta mempersiapkan apa saja yang dibutuhkan dalam kegiatan tersebut.

Dukungan tenaga pendidik terhadap penciptaan budaya religius di sekolah adalah sebagai berikut Orangtua yang melakukan zakat fitrah dan zakat mal disekolah tidak di rumah, orangtua yang ikut menyiapkan takjil untuk anaknya yang kemudian dibawa ke sekolah, berdirinya masjid SMAN 9 Malang merupakan gagasan dari orangtua siswa yang menjabat sebagai komite sekolah yang kemudian disetujui oleh pihak sekolah dengan dana sumbangan dari siswa maupun orangtua siswa serta kotak amal yang dilakukan setiap minggu.

\section{Cara Mengatasi Masalah dalam Menciptakan Budaya Religius}

Pihak sekolah dalam mengatasi setiap masalah yang ada pada penciptaan budaya religius adalah dengan cara evaluasi. Evaluasi pada awalnya dilakukan oleh tim inti yaitu pada rapat kecil yang beranggotakan Unit Penjamin Mutu, Para Wakil Kepala Sekolah, Bendahara, Ketua Panitia, pada rapat ini mencari kesalahan maupun kekurangan dari setiap kegiatan yang sudah dilakukan beserta mencari solusi dari kendala tersebut. Setelah rapat dengan tim inti selesai barulah hasil dari rapat disampaikan kepada seluruh guru melalui rapat untuk mencari solusi dari setiap masalah, tidak menutup kemungkinan akan muncul kekurangan dari setiap kegiatan menurut para guru, dengan rapat tersebut maka akan dihasilkan solusi yang terbaik untuk mengatasi setiap masalah yang ada 


\section{PEMBAHASAN}

\section{Langkah-Langkah Kepala Sekolah dalam Menciptakan Budaya Religius}

Langkah-langkah Kepala Sekolah dalam menciptakan budaya religius diawali dengan rapat kecil yang beranggotakan Kepala Sekolah, Unit Penjamin Mutu, Wakil Kepala Sekolah, Bendahara, dan Komite Sekolah. Hal ini sependapat dengan Wiyono (2013:39) bahwa tugas seorang kepala sekolah adalah merencanakan, mengorganisir, mengkoordinir, melakukan komunikasi, mempengaruhi, dan mengadakan evaluasi merupakan komponen-komponen tugas proses. Serta sesuai dengan penelitian Faturahman (2018) bahwa kepala sekolah hendaknya dapat mengadakan rapat dengan warga sekolah yakni wakil kepala sekolah, guru, bendahara, komite, dan stakeholders. Rapat tersebut dipimpin oleh kepala sekolah sebagai pimpinan lembaga. Dalam merencanakan sebuah program kegiatan kepala sekolah memang seharusnya mengajak warga sekolah lainnya untuk ikut bergabung menyusun dan merencanakan karena dapat memberikan masukan masukan serta usulan terkait program yang baik untuk dilakukan kedepannya.

Dalam rapat tersebut dilakukan perencanaan kegiatan apa saja yang akan dilakukan selama setahun kedepan, kemudian menentukan besaran biaya yang akan dikeluarkan dalam kegiatan tersebut, serta juga menentukan siapa saja guru yang terlibat dalam kegiatan tersebut dan membuat susunan panitianya. Hal ini sesuai dengan penelitian Baihaki (2016) bahwa pada dasarnya perencanaan merupakan suatu kegiatan yang terstruktur secara sistematis mengenai suatu hal untuk mencapai suatu tujuan, kegiatan yang akan dilakukan, langkah-langkah yang akan dilakukan, metode-metode yang akan digunakan, pelaksana kegiatan yang dibutuhkan untuk menyelenggarakan suatu kegiatan untuk mencapai tujuan.

Hasil dari rapat kecil tersebut kemudian di sampaikan ke forum rapat semua guru untuk menindaklanjuti hasil dari rapat kecil yang sudah dilaksanakan. Dalam rapat bersama guru masih ada kemungkinan perubahan dari rencana kegiatan karena adanya masukan-masukan dari guru. Semakin banyaknya yang ikut menyusun serta merencanakan suatu program maka akan semakin banyak pula masukan serta ide-ide yang akan ditemukan sehingga program yang akan dilakukan benar-benar yang terbaik untuk dilakukan.

Seperti yang dikemukakan oleh Baihaki (2016) perencanaan sekolah tidak harus murni ide dari kepala sekolah namun bisa juga ide atau gagasan dari siswa, guru, serta karyawan. Kepala sekolah juga bisa mengambil usulan dari ide-ide yang diungkapkan oleh warga sekolah, kemudian gagasan akan diambil apabila tepat atau mungkin bisa diambil. Kepala sekolah juga dapat memusyawarahkan ide atau gagasan program yang akan direalisasikan dalam rapat maupun pertemuan-pertemuan dengan warga sekolah.

Perencanaan yang dilakukan oleh kepala SMAN 9 Malang dalam mewujudkan budaya religius melalui program kegiatan nilai-nilai keagamaan merupakan salah satu fungsi kepala sekolah sebagai manajer dan perencana, yaitu merencanakan yeng terbaik untuk kegiatan budaya religius di sekolah, serta diharuskan untuk kreatif serta inovatif dalam gagasan pemikirian untuk mewujudkan budaya religius di lingkungan sekolah.

\section{Bentuk Budaya Religius}

Bentuk-bentuk budaya religius yang ada di SMAN 9 Malang berdasarkan kegiatan yang dilakukan sehari-hari adalah siswa didengarkan lantunan Asmaul Husna ketika siswa tiba disekolah melalui pengeras suara sekolah. Literasi, dilakukan 15 menit sebelum pelajaran dimulai, siswa muslim melakukan literasi di kelas masing-masing yang dipandu oleh salah satu siswa membaca ayat Al-Qur'an melalui pengeras suara sekolah. Sedangkan non muslim melaksanakan literasi di aula sekolah berkelompok berdasarkan agama. Berdoa sebelum pelajaran dimulai, dilakukan pada saat sebelum pelajaran dimulai yang dipimpin oleh guru mata pelajaran. Salat Dhuha, saat pelajaran agama diberikan waktu sekitar 10menit untuk melaksanakan Salat Dhuha, dan pada hari sabtu setelah kegiatan pramuka. Salat Dhuhur dan Ashar berjamaah, Salat Dhuhur dilaksanakan pada istirahat kedua, Salat Ashar dilaksanakan saat setelah bel pulang sekolah. Kultum, setelah adzan Salat Dhuhur siswa siswa diberikan kajian kitab kuning tentang ta'lim muta'alim baru kemudian dilaksanakan Salat Dhuhur berjamaah. Doa sebelum 
pulang sekolah, salah satu siswa memimpin doa melalui pengeras suara sekolah sebelum pulang ke rumah masing-masing.

Salah satu langkah kongkrit untuk mewujudkan budaya religius di lembaga pendidikan menurut Koentjaraningrat (2006) adalah melalui tataran praktik keseharian. Tataran praktik keseharian, nilai-nilai religiusyang telah disepakati diwujudkan dalam bentuk sikap dan perilaku keseharian oleh semua warga sekolah. Proses pengembangan tersebut dapat dilakukan melalui tiga tahap (Fathurrohman, 2016), yaitu (1) sosialisasi nilai-nilai religius yang disepakati, (2) penetapan action plan sebagai tahapan dan langkah sistematis yang akan dilakukan oleh lembaga pendidikan dalam mewujudkan nilai-nilai religius tersebut, dan (3) pemberian penghargaan terhadap prestasi warga sekolah, seperti guru, tenaga kependidikan, dan siswa sebagai usaha pembiasaan yang menjunjung sikap dan perilaku yang berkomitmen terhadap ajaran religius yang telah disepakati.

Bentuk budaya religius yang dilakukan setiap minggu adalah siswa dilatih untuk bershodaqoh setiap hari jumat ada kotak amal keliling per kelas dan pada saat Salat jum'at. Dilaksanakan Salat jumat berjamaah untuk siswa putra dan kegiatan keputrian untuk siswi putri, sedangkan siswa non muslim ada pembinaan keagamaan. Siswa juga dilatih untuk menjadi qotib Salat jum'at yang dilakukan bergantian dengan guru setiap minggu. Pada hari sabtu setelah siswa melaksanakan kegiatan pramuka dan mendpat materi PPK selanjutnya siswa diarahkan ke masjid untuk Salat Dhuha dan mendpat materi keagamaan tentang tajwid dan tahsin, sedangkan yang non muslim diarahkan ke aula untuk mendapat materi keagamaan sesuai agama masing-masing.

Bentuk budaya religius yang dilakukan setiap bulan adalah kunjungan ke rumah siswa bersama dengan bapak ibu guru, kemudian 2 bulan menjelang ujian nasional siswa kelas 12 melaksanakan istighosah kubro dan diakhir melakukan istighosah bersama dengan orangtua yang dilanjutkan dengan parenting.

Bentuk budaya religius yang dilakukan setiap tahun adalah kegiatan pondok ramadan, peringatan maulid Nabi Muhammad, peringatan hari raya idul adha, peringatan keagamaan untuk non muslim, serta Islamic Competition.Hal ini sesuai dengan temuan penelitain Suryana dan Maryamah (2013) dilihat dari waktu pelaksanaannya kegiatan budaya religius ada yang dilaksanakan secara rutin, baik secara harian, mingguan, bulanan, maupun tahunan. Berbagai kegiatan budaya religius yang dilaksanakan oleh sekolah, diharapkan dapat menjadi jalan untuk menciptakan sikap, mental, dan berkembanganya potensi yang positif pada diri siswa, sehingga dapat memicu karakter religiusitas dan ajaran-ajaran atau budaya religius dapat dijadikan sebagai pedoman dalam kehidupan sehari-hari.

\section{Sosialisasi dan Implementasi Budaya Religius}

Menurut Mulyono (2011) teknik humas yang dapat digunakan untuk mensosialisasikan kegiatan budaya religius adalah pameran, menyebarkan brosusr, memasang spanduk, iklan di radio, TV atau media cetak, pertemuan walimurid, menghadiri pertemuan, kunjungan rumah, perpisahan, bakti sosial, temu alumni, kerjasama dengan lembaga lain. Sesuai dengan pendapat tersebut pihak sekolah dalam mensosialisaskian setiap kegiatan dilakukan dengan melalui media cetak dan elektronik yang mempunyai rekanan di koran Jawa Pos dan Arema TV.

Pihak sekolah juga menyampaikan kegiatan-kegiatan dan informasi secara langsung melalui pertemuan wali murid, parenting, dan pada saat pembagian raport. Dengan adanya sosialisasi kegiatan dari pihak sekolah maka seluruh masyarakat terutama orangtua akan mengetahui terkait kegiatankegiatan yang dilaksanakan oleh sekolah. Senada dengan penelitian Yulitasari, Maisyaroh, dan Soetopo (2018) penyampaian informasi kegiatan sekolah ditujukan kepada publik atau masyarakat diluar warga sekolah, yang bisa dilakukan secara langsung (tatap muka) misalnya, rapat bersama dengan pengurus komite sekolah setempat, berkonsultasi dengan tokoh-tokoh masyarakat, melayani kunjungan tamu dan tidak langsung melalui perantaraan media tertenu, misalnya telepon internet, faksimili, TV, radio, majalah sekolah, mading sekolah, dan media cetak umum.

Pihak sekolah juga menyampaikan informasi melalui media sosial yaitu penyampaian informasi di akun facebook, instagram, serta group whatsaapp ketua kelas dan orangtua. Selain menggunakan media 
sosial yaitu penyampaian informasi kegiatan sekolah melalui media online dalam menyampaikan setiap kegiatan dan pusat informasi sekolah yang ada di website sekolah. sesuai dengan pendapat Wang (2015) "social media have been exerting a substantial impact on many disciplines and practices such as mass communication and public relations. In particular, social media have spurred many research topics and opportunities in public relations fields". Media sosial dapat digunakan untuk berkomunikasi dengan pihak internal maupun eksternal lembaga.

Sekolah sudah mengimplementasikan strategi yang sudah dirancang dari tahap perencanaan, pelaksanaan, dan pembiasaan di kesehariandi lingkungan sekolah. seperti siswa menjadi lebih sopan dan santun kepada guru maupun tenaga kependidikan dengan budaya 5S (senyum, sapa, salam, sopan, santun). Siswa juga menjadi disiplin dengan dibiasakannya Salat Dhuhur dan Salah Ashar berjamaah ditunjukkan dengan siswa lebih sedikit yang datang terlambat ke sekolah. siswa juga menjadi lebih dermawan dengan pembiasaan kotak amal keliling setiap hari jumat dan iuran untuk membeli hewan qurban dibuktikan dengan terbangunnya masjid SMAN 9 Malang dan setiap Peringatan Idul Adha sekolah selalu menyembelih hewan qurban.

Seperti pendapat dari Masitoh (2017) Implementasi budaya religius sebagai upaya pengembangan sikap sosial siswa adalah bahwa siswa lebih rendah hati dengan adanya budaya taddarus central morning, siswa lebih jujur dan disiplin dengan pembiasaan Salat Dhuha dan pembiasaan Salat Dhuhur berjamaah ditunjukkan dengan berangakat sekolah tepat waktu, Salat tepat waktu dan berjalannya kembali kantin kejujuran disekolah, siswa lebih santun berbicara dengan adanya pembiasaan khutbah jumat yang ditugaskan kepada siswa, siswa tidak lagi membentuk kelompok-kelompok kecil dengan adanya pembiasaan kepantitaan dalam acara Peringatan Hari Besar Islam (PHBI) yang ditanggungjawabkan kepada siswa, siswa lebih bersikap toleransi dengan budaya mentoring dan kegiatan pesantren kilat bulan Ramadhan karena secara langsung siswa berhadapan dengan banyak orang yang berbeda karakter dan pemikirannya.

\section{Dukungan Guru dan Warga Sekolah dalam Menciptakan Budaya Religius}

Dukungan guru terhadap terlaksananya penciptaan budaya religius adalah sebagai berikut guru memberikan contoh yang baik untuk siswanya melalui baris di pagi hari di halaman sekolah untuk menyambut siswa, ke masjid saat bel istirahat berbunyi untuk menjalankan Salat Dhuhur berjmaah, setiap sebelum kegiatan belajar mengajar dimulai diawali dengan berdoa terlebih dahulu, beberapa guru menganjurkan untuk melaksanakan Salat Dhuha terlebih dahulu sebelum pelajaran dimulai, dan selalu mendukung setiap kegiatan budaya religius yang ada disekolah.

Sesuai dengan Lestari (2016) bahwa penciptaan budaya religius disekolah dilakukan dengan cara internalisasi nilai baik dalam proses pembelajaran maupun diluar jam pembelajaran, melalui kegiatan pembiasaan yang diterapkan disekolah, dan kegiatan ekstrakurikuler. Peran guru dalam menciptakan budaya religius tersebut antara lain sebagai teladan atau contoh, sebagai penginternalisasi nilai-nilai, sebagai motivator kegiatan religius, dan sebagai pembimbing kegiatan religius. Peran dari guru adalah yang paling besar pengaruhnya terhadap terciptanya budaya religus disekolah karena yang mengajarkan dan memberikan contoh secara langsung nilai-nilai religius kepada siswa adalah guru.

Dukungan siswa terhadap terlaksananya penciptaan budaya religius di sekolah adalah sebagai berikut dipilihnya salah satu siswa yang memimpin literasi dan bergantian setiap hari, siswa yang ikut BDI maupun Remas membantu kegiatan religius yang ada di sekolah, misalnya saat penyembelihan hewan qurban siswa ikut membantu memotong dan membagikan hewan qurban, siswa membersihkan dan mempersiapkan masjid yang akan digunakan untuk Salat berjamaah mauapun Salat jum'at, siswa yang diberi tugas untuk menjadi qotib pada saat Salat jum'at, membaca Al-Qur'an di masjid sekolah pada saat bulan Ramadhan.

Sependapat dengan temuan Suryana dalam penelitiannya (2013) bahwa dukungan siswa dalam menciptakan budaya religius disekolah adalah dengan membangun komitmen bersama, sesama siswa saling mengingatkan jika ada yang melanggar, teladan kakak kelas dalam pelaksanaan orientasi siswa baru yaitu para kakak kelas menanamkan senyuman dan sapaan ketika bertemu dengan semua warga sekolah, serta siswa-siswi disekolah patuh terhadap kebijakan kepala sekolah dalam penciptaan budaya 
religius seperti selalu melaksanakan Salat berjamah, membudayakan senyum, sapa, salam, aktif terhadap kegiatan keagamaan.

Dukungan tenaga pendidik terhadap penciptaan budaya religius di sekolah adalah sebagai berikut setiap hari selasa-jumat dilakukan apel pagi untuk tenaga pendidik untuk memberikan informasi terkait kegiatan yang akan dilakukan pada hari itu, sehingga tenaga pendidik bisa mendukung kelancaran kegiatan tersebut dan ikut serta mempersiapkan apa saja yang dibutuhkan dalam kegiatan tersebut.

Sesuai dengan pendapat Noor (2015) budaya religius disekolah tercipta atas dasar totalitas pola kehidupan civitas sekolah yang lahir dan ditransmisikan bersama, mulai dari kepala sekolah, pendidik, tenaga kependidikan, peserta didik, stakeholder, dan sebagainya yang dilandsi oleh keimanan kepada Tuhan. Sehingga pemikiran, perbuatan dan pembiasaan civitas sekolah akan selalu berlandaskan pada keimanan dan terpancar pada pribadi dan perilaku sehari-hari.

Menurut Baihaki (2016) budaya religius yang sudah ada disekolah akan lebih maksimal lagi untuk siswa apabila peran orangtua dirumah juga besar karena siswa hanya sebentar berada disekolah. Dengan hal itu penanaman iman atau nilai-nilai agama lebih efektif apabila dilakukan juga di rumah oleh orangtua siswa. Karena itu perlu adanya kerjasama antara orangtua siswa dengan kepala sekolah, guru, dan warga sekolah. sebab tidak semua orangtua mengetahui dan mengerti apa yang seharusnya dilakukan di rumah dalam rangka menanamkan religiusitas pada anaknya. Melalui kerjasama ini diharapkan pihak sekolah memberikan saran-sarannya kepada orangtua siswa.

Senada dengan pendapat tersebut dukungan orangtua terhadap penciptaan budaya religius di sekolah adalah sebagai berikut Orangtua yang melakukan zakat fitrah dan zakat mal disekolah tidak di rumah, orangtua yang ikut menyiapkan takjil untuk anaknya yang kemudian dibawa ke sekolah, berdirinya masjid SMAN 9 Malang merupakan gagasan dari orangtua siswa yang menjabat sebagai komite sekolah yang kemudian disetujui oleh pihak sekolah dengan dana sumbangan dari siswa maupun orangtua siswa serta kotak amal yang dilakukan setiap minggu.

\section{Cara Mengatasi Masalah dalam Menciptakan Budaya Religius}

Pihak sekolah dalam mengatasi setiap masalah yang ada pada penciptaan budaya religius adalah dengan cara evaluasi. Evaluasi pada awalnya dilakukan oleh tim melalui rapat yang beranggotakan Unit Penjamin Mutu, Para Wakil Kepala Sekolah, Bendahara, Ketua Panitia, pada rapat ini mencari kesalahan maupun kekurangan dari setiap kegiatan yang sudah dilakukan beserta mencari solusi dari kendala tersebut.

Berdasarkan temuan penelitian Maisaro, Wiyono, dan Arifin (2018) menyatakan bahwa evaluasi program kegiatan dilakukan oleh kepala sekolah sebagai pimpinan tertinggi disekolah dibantu oleh tim pengembang sekolah serta koordinator sekolah. kepala sekolah dapat membentuk tim yang beranggotakan guru-guru senior atau guru yang dianggap berkompeten untuk mengevaluasi program kegiatan penciptaan budaya religius di sekolah. hasil evaluasi dapat dijadikan bahan masukan oleh kepala sekolah untuk perencanaan atau pembuatan kebijakan dalam rangka penyusunan program penciptaan budaya religius siswa.

Setelah rapat dengan tim inti selesai barulah hasil dari rapat disampaikan kepada seluruh guru melalui rapat untuk mencari solusi dari setiap masalah, tidak menutup kemungkinan akan muncul kekurangan dari setiap kegiatan menurut para guru, dengan rapat tersebut maka akan dihasilkan solusi yang terbaik untuk mengatasi setiap masalah yang ada. Senada dengan pendapat Lazwardi (2017) yang menyatakan bahwa setiap program kegiatan yang telah direncanakan perlu diakhiri dengan evaluasi. Evaluasi ini bertujuan untuk meninjau kembali apakah program tersebut dilaksanakan sesuai dengan rencana dan tujuan yang telah ditetapkan. Selanjutnya dari hasil evaluasi dapat diambil keputusan apakah program akan diteruskan, direvisi, atau bahkan dihentikan karena menimbulkan banyak masalah atau bisa juga dirumuskan kembali dan disesuaikan dengan tujuan, sasaran, serta alternatif baru yang berbeda dengan sebelumnya. 


\section{KESIMPULAN DAN SARAN}

\section{Kesimpulan}

Strategi kepala sekolah dalam menciptakan budaya religius adalah dengan merencanakan terlebih dahulu dengan unit penjamin mutu, wakil kepala sekolah, bendahara, dan komite sekolah terkait kegiatan, menentukan besaran biaya, menentukan guru yang terlibat dan mendiskusikan terkait budaya religius yang sudah ada disekolah yang perlu dipertahankan, diperbaiki, maupun dirubah Hasil dari rapat tersebut kemudian di musyawarahkan ke forum rapat semua guru untuk menindaklanjuti hasil dari rapat yang sudah dilaksanakan untuk mendapatkan budaya religius yang terbaik dilakukan disekolah. Kegiatan yang sudah direncanakan dibagi menjadi fiqih, aqidah akhlaq, qur'an hadits, mu'amalah, sejarah kebudayaan islam, dan penguatan keagamaan. Phak sekolah juga melakukan sosialisasi kegiatan budaya religius melalui media sosial, media cetak, media elektronik, website sekolah, serta secara lisan. Pihak sekolah dalam mengatasi setiap masalah yang ada pada penciptaan budaya religius adalah dengan cara evaluasi. Evaluasi pada awalnya dilakukan oleh tim inti yaitu pada rapat yang beranggotakan Unit Penjamin Mutu, Para Wakil Kepala Sekolah, Bendahara, Ketua Panitia, pada rapat ini mencari kesalahan maupun kekurangan dari setiap kegiatan yang sudah dilakukan beserta mencari solusi dari kendala tersebut. Setelah rapat dengan tim inti selesai barulah hasil dari rapat disampaikan kepada seluruh guru melalui rapat untuk mencari solusi dari setiap masalah, tidak menutup kemungkinan akan muncul kekurangan dari setiap kegiatan menurut para guru, dengan rapat tersebut maka akan dihasilkan solusi yang terbaik untuk mengatasi setiap masalah yang ada.

\section{Saran}

Saran yang diberikan peneliti berdasarkan hasil penelitian yaitu; bagi peneliti lain. Peneliti menemukan strategi-strategi kepala sekolah dalam menciptakan budaya religius. Maka dari itu disarankan untuk peneliti lain agar dapat menindaklanjuti penelitian ini lebih dalam baik dengan metode yang sama yaitu kualitatif atau dengan metode yang berbeda yaitu kuantitatif. Peneliti lain juga disarankan melanjutkan penelitian ini dikarenakan banyak faktor pembuktian lain yang belum tertera dalam penelitian ini sehingga dapat muncul hasil-hasil yang nantinya diharapkan dapat menjadi penelitian yang lebih aktual dan bisa menjadi bahan rujukan bagi penelitian selanjutnya.

\section{DAFTAR RUJUKAN}

Adha, M.A., Supriyanto, A., \& Timan, A. 2019. Strategi Peningkatan Mutu Lulusan Madrasah Menggunakan Diagram Fishbone. Tarbawi: Jurnal Keilmuan Manajemen Pendidikan, 5 (1), 11-22.

As'aril, M. 2011. Ilmu Pendidikan Perspektif Kontekstual. Jogjakarta: Ar-Ruzz Media.

Baihaki, A. 2016. Strategi Kepala Sekolah dalam Mewujudkan Budaya Religius di MA Negeri dan SMA Negeri 1 Sumenep Madura. Tesis Tidak diterbitkan. Universitas Islam Negeri Maulana Malik Ibrahim Malang.

Fathurrohman, M. 2016. Pengembangan Budaya Religius dalam Meningkatkan Mutu Pendidikan. Ta'alum, 4 (1), $19-41$.

Faturahman, B.M. 2018. Kepemimpinan dalam Budaya Organisasi. Madani. 10 (1) 1-11.

Koentjaraningrat. 2006. Kebudayaan, Mentalitas, dan Pembangunan. Jakarta: Raja Grafindo Persada.

Lestari, P. 2016. Peran Guru dalam Implementasi Budaya Religius di MIN Wonosari. Skripsi Tidak diterbitkan. Universitas Islam Negeri Sunan Kalijaga Yogyakarta.

Maisaro, A., Wiyono, B.B., dan Arifin, I. 2018. Manajemen Program Penguatan Pendidikan Karakter di Sekolah Dasar. Jurnal Administrasi dan Manajemen Pendidikan, 1 (3), 302-312.

Masitoh, U. 2017. Implementasi Budaya Religius Sebagai Upaya Pengembangan Sikap Sosial Siswa di SMA Negeri 5 Yogyakarta. Tesis Tidak diterbitkan. Universitas Islam Negeri Sunan Kalijaga Yogyakarta.

Muhaimin, Sutiah, dan Prabowo, S.L., 2010. Manajemen Pendidikan, Aplikasinya dalam Menyusun Pengembangan Sekolah/Madrasah. Jakarta: Kencana.

Mulyono. 2011. Manajemen Humas pada Lembaga Pendidikan Islam. Ulumuna, 15 (1), 165-184.

Noor, W. 2015. Budaya Religius di Sekolah/Madrasah. At-Tarbiyah. 6 (1), 87-101. 
Qanita S. 2016. Krisis Moral Mengancam Generasi Muda. (Online) (http://suluhbali.co/artikel-krisis-moralmengancam-generasi-muda), diakses 21 April 2018.

Suryana, E., dan Maryamah. 2013. Pembinaan Keberagamaan Siswa Melalui Pengembangan Budaya Agama di SMA Negeri 16 Palembang. Ta'dib, 17 (2), 169-191. Dari http://jurnal.radenfatah.ac.id/index.php/tadib/ article/download/45/40.

Wang. Y. 2015. Incorporating Social Media in Public Relations: A Synthesis of Social Media-Related Public Relations Research. PR Journal, 9 (3), 2. Dari https://www.prsa.org/Intelligence/PRJournal/ Documents/2015v09n03Yan g.pdf.

Wiyono, B.B. 2013. Kepemimpinan Transformasional Kepala Sekolah (Konsep, Pengukuran, dan Pengembangannya). Malang: Fakultas Ilmu Pendidikan Univeritas Negeri Malang.

Yulitasari, E., Maisyaroh., dan Soetopo, H. 2018. Pelaksanaan Hubungan Sekolah dan Masyarakat di Sekolah Berbasis Pesantren. Skripsi tidak diterbitkan. Universitas Negeri Malang. 